\title{
Effect of pre-sintering of raw material powder on properties of solid oxide fuel cell electrolyte prepared by dip-coating method
}

\author{
Masaaki IZUMI ${ }^{\dagger}$ and Noboru SASAHARA* \\ Faculty of Environmental Engineering, The University of Kitakyushu, \\ 1-1 Hibikino, Wakamatsu-ku, Kitakyushu, Fukuoka 808-0135 \\ *Graduate School of Environmental Engineering, The University of Kitakyushu, \\ 1-1 Hibikino, Wakamatsu-ku, Kitakyushu, Fukuoka 808-0135
}

\begin{abstract}
In order to remedy defects of thin electrolyte films, which significantly affect the power generation performance of solid oxide fuel cells (SOFCs), the effects of pre-sintering of raw material powder $\left(8 \mathrm{~mol} \% \mathrm{Y}_{2} \mathrm{O}_{3}\right.$-stabilized $\mathrm{ZrO}_{2}$ : YSZ) on the properties of the electrolyte were investigated. After pre-sintering YSZ powder under various temperature and time conditions, electrolytes (about $30 \mu \mathrm{m}$ in thickness) were deposited on the substrates of fuel electrodes by a dip-coating method and then co-sintered. The microstructures of the electrolytes were observed by scanning electron microscopy and laser scanning confocal microscopy. The power generation performance of fabricated cells was also investigated. As a result, the electrolyte fabricated by pre-sintering YSZ powder at $200^{\circ} \mathrm{C}$ for $120 \mathrm{~h}$ was found to be dense and impermeable. The cell containing the electrolyte showed reasonable power generation performance. In the case where the pre-sintering temperature was maintained at $200^{\circ} \mathrm{C}$ and the pre-sintering time was shortened to $20 \mathrm{~h}$, the electrolyte was found to be porous, and the open circuit voltage of the cell was lower than the theoretical value. By increasing the pre-sintering temperature to $600^{\circ} \mathrm{C}$ for $20 \mathrm{~h}$, an ideal electrolyte could be obtained. In contrast, the electrolyte fabricated using the YSZ powder without pre-sintering was highly porous, leading to a considerable drop in open circuit voltage.
\end{abstract}

(C2010 The Ceramic Society of Japan. All rights reserved.

Key-words : Solid oxide fuel cell, Electrolyte, Raw material powder, Pre-sintering, Dip-coating, Open circuit voltage, YSZ

[Received April 19, 2010; Accepted August 19, 2010]

\section{Introduction}

Since solid oxide fuel cells (SOFCs) operate at high temperature, a high reaction rate and high energy conversion efficiency are ensured without the need for expensive catalysts such as platinum. The electrolyte management issues that arise with other types of fuel cells do not occur, because SOFCs are complete solid-state devices that use a ceramic material as the electrolyte. However, the high operating temperature poses problems of insufficient durability and reliability. ${ }^{1), 2)}$

To solve these problems, research and development of SOFCs has focused on the reduction of operating temperature. However, the reduction of operating temperature causes the increase of several overpotentials, especially of the ohmic loss of the electrolyte. The increase in the ohmic loss can be overcome by several measures such as the formation of thinner electrolytes ${ }^{3)-6 \text { ) }}$ and electrolytes with higher ionic conductivity. ${ }^{7-10)}$ The use of thinner electrolytes can be realized by electrode-supported cells. However, using a thinner electrolyte in a cell increases the risk of deterioration in cell performance, because the presence of open pores in the thinner electrolyte increases the gas permeability of the electrolyte.

In this study, an electrolyte layer was deposited on a fuel electrode by a dip-coating method and then co-sintered. The effects of pre-sintering of the raw material powder of the electrolyte used for a suspension in the dip-coating method were investigated. The properties of the electrolyte were evaluated by scanning electron microscopy (SEM), laser scanning confocal

\footnotetext{
Corresponding author: M. Izumi; E-mail: izumi@env.kitakyu-u. ac.jp
}

microscopy (LSCM), and the Vickers hardness test. The cell performance was also tested between 800 and $1000^{\circ} \mathrm{C}$ with humidified hydrogen as a fuel and air as an oxidant.

\section{Experimental}

\subsection{Cell fabrication}

Figure 1 shows the procedure for fabricating cells. The fuel electrode was extrusion-molded in the form of a flat plate after preparing a powder. The fuel electrode was made of $\mathrm{NiO}$ powder and YSZ ( $8 \mathrm{~mol} \% \mathrm{Y}_{2} \mathrm{O}_{3}$-stabilized $\mathrm{ZrO}_{2}$, TZ-8YS, Tosoh Co.,

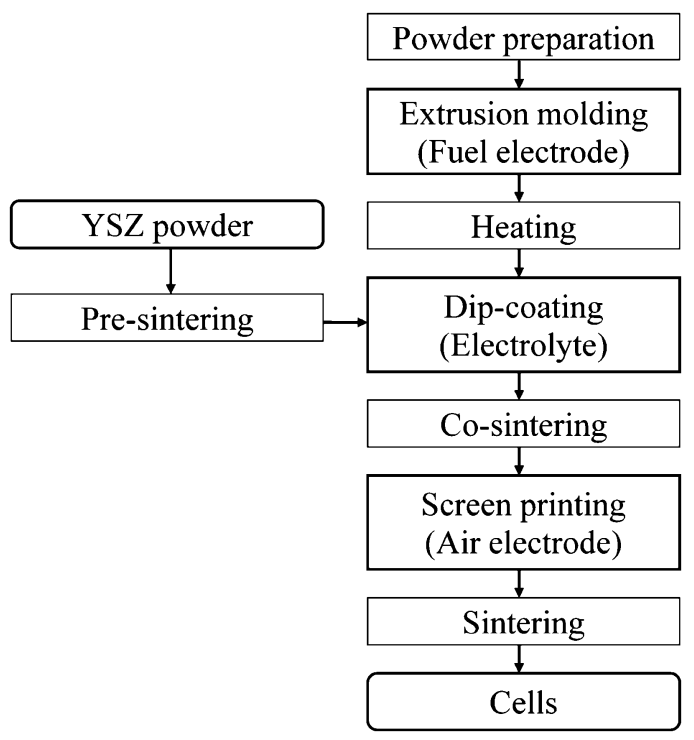

Fig. 1. Cell fabrication process. 
Table 1. Conditions for pre-sintering YSZ (raw material) powder ( $\circ$ : investigated, $\times$ : not investigated)

\begin{tabular}{cccc}
\hline \multirow{2}{*}{ Temp. } & \multicolumn{3}{c}{ Time } \\
\cline { 2 - 4 } & $20 \mathrm{~h}$ & $100 \mathrm{~h}$ & $120 \mathrm{~h}$ \\
\hline $200^{\circ} \mathrm{C}$ & $\circ$ & $\times$ & $\circ$ \\
$400^{\circ} \mathrm{C}$ & $\circ$ & $\circ$ & $\times$ \\
$600^{\circ} \mathrm{C}$ & $\circ$ & $\times$ & $\times$ \\
\hline
\end{tabular}

Ltd.) powder, which were mixed at a mass ratio of $1: 1$. The green substrates were produced by Kyushuceramics Industries Co., Ltd. Each of the green substrates, after drying, was heated at $1100^{\circ} \mathrm{C}$ in air. The heated substrate was dipped into an YSZ suspension and then dried. The YSZ suspension was prepared by mixing $8.4 \mathrm{~g}$ of YSZ powder with $200 \mathrm{~cm}^{3}$ of organic solvent (ethanol, $>99.5 \%$, Kanto Chemical Co., Inc.). An additional process was performed to dehydrate the organic solvent. The dipping and drying processes were repeated until the mass of deposited YSZ reached a prescribed amount. The green body of YSZ and NiO-YSZ laminate was co-sintered at $1450^{\circ} \mathrm{C}$ in air. Slurry which contained $100 \mathrm{~g}$ of $\mathrm{La}_{0.8} \mathrm{Sr}_{0.2} \mathrm{MnO}_{3}$ powder (LSM-80, Daiichi Kigenso Kagaku Kougyo Co., Ltd.), $20 \mathrm{~g}$ of carbon as a pore-forming agent, and an adequate amount of alpha-terpineol was screen-printed as the air electrode onto the electrolyte and sintered at $1350^{\circ} \mathrm{C}$ in air. Finally, the electrolyte film on the opposite surface to the air electrode was removed by grinding.

The completed cell was $32 \mathrm{~mm}$ by $24 \mathrm{~mm}$, and $1.2 \mathrm{~mm}$ in thickness. The electrolyte was about $30 \mu \mathrm{m}$ in thickness. The air electrode was $10 \mathrm{~mm}$ by $10 \mathrm{~mm}$, and $100-200 \mu \mathrm{m}$ in thickness.

In this study, the YSZ powders of raw material used for the aforementioned dip-coating method were pre-sintered under various conditions as shown in Table 1. The effects of the presintering on properties of the electrolyte were examined and also compared with the case in which the YSZ powder was not presintered.

\subsection{Evaluation of electrolyte}

The microstructure of the electrolyte surface was observed by SEM. The surface roughness of the electrolyte was also measured by LSCM. The surface roughness was measured for five lines of $128 \mu \mathrm{m}$ in length on each specimen, and then averaged. The Vickers hardness of the electrolyte was measured at five points on each specimen under the condition of a load of $9.8 \mathrm{~N}$, and then averaged. The specimens without the air electrodes after the formation of the electrolyte were used for the SEM observation, the roughness and hardness tests.

The cell performance ( $I-V$ characteristics) was measured at $800-1000^{\circ} \mathrm{C}$ while controlling the generated current with an electric-load device. The fuel cell was fed with $\mathrm{H}_{2}$ as a fuel gas at a flow rate of $100 \mathrm{ml} / \mathrm{min}$ after humidifying $\mathrm{H}_{2}$ at room temperature. Air fed to the fuel cell at a flow rate of $100 \mathrm{ml} / \mathrm{min}$ was used as the oxidant. The measured open circuit voltage (OCV) was compared with the theoretical value $E$, which was calculated using the following equation. ${ }^{11)}$

$$
E=\frac{R T}{4 F} \ln \left(\frac{p_{\mathrm{O} 2, c}}{p_{\mathrm{O} 2, a}}\right)
$$

Here, $R$ is the gas constant, $T$ is the operating temperature, $F$ is the Faraday constant, and $p_{\mathrm{O} 2}$ is the partial pressure of oxygen. The subscripts of $a$ and $c$ denote the sides of the fuel electrode and the air electrode, respectively.
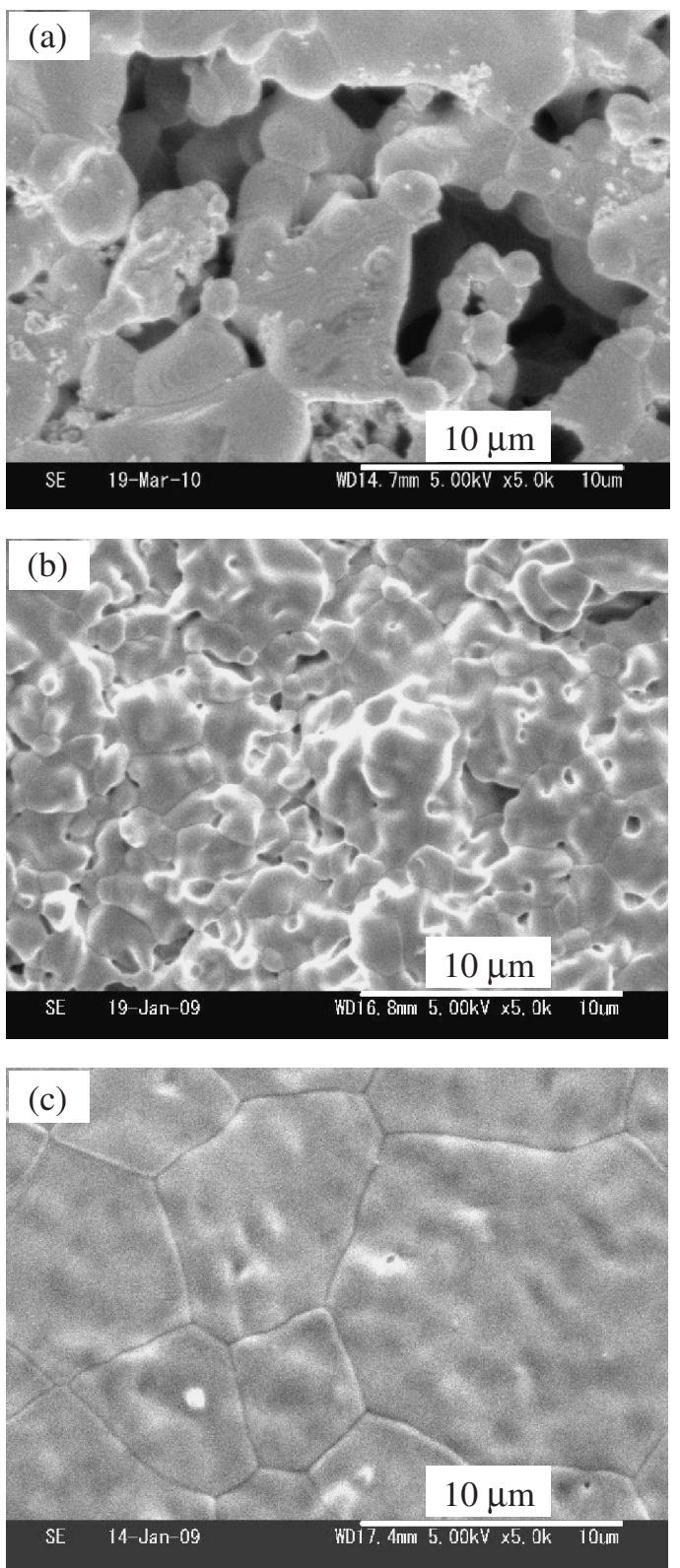

Fig. 2. SEM images of electrolyte surface: (a) without pre-sintering, (b) pre-sintered at $200^{\circ} \mathrm{C}$ for $20 \mathrm{~h}$, and (c) pre-sintered at $200^{\circ} \mathrm{C}$ for $120 \mathrm{~h}$.

\section{Results and discussion}

Figure 2 shows SEM images of the electrolyte surfaces. Figure 2(a) shows a SEM image of the electrolyte formed using the YSZ powder that was not pre-sintered. The microstructure of the electrolyte is highly porous and has some large pores. Although the electrolyte is improved by pre-sintering at $200^{\circ} \mathrm{C}$ for $20 \mathrm{~h}$, some small pores are still observed as shown in Fig. 2(b). However, Fig. 2(c) shows that the YSZ powder can be sintered to form a YSZ electrolyte film that is extremely dense by extending the pre-sintering time and maintaining a pre-sintering temperature of $200^{\circ} \mathrm{C}$.

Figure 3 shows the results of the surface roughness of the electrolyte film measured with the LSCM. The average maximum height $R_{\mathrm{z}}$ of the electrolyte film obtained using the YSZ powder pre-sintered at $200^{\circ} \mathrm{C}$ for $20 \mathrm{~h}$ is $1.2 \mu \mathrm{m}$. The values of $R_{\mathrm{z}}$ are almost independent of temperature and time for pre-sintering 


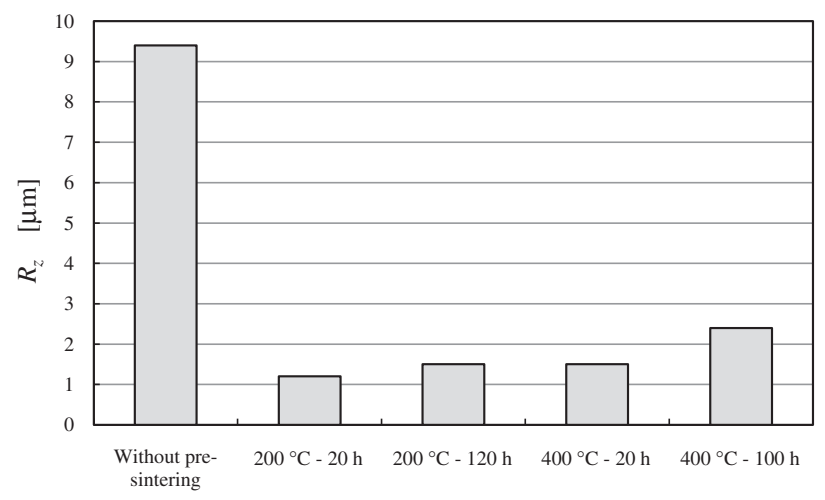

Fig. 3. Maximum height of surface roughness $R_{\mathrm{z}}$.

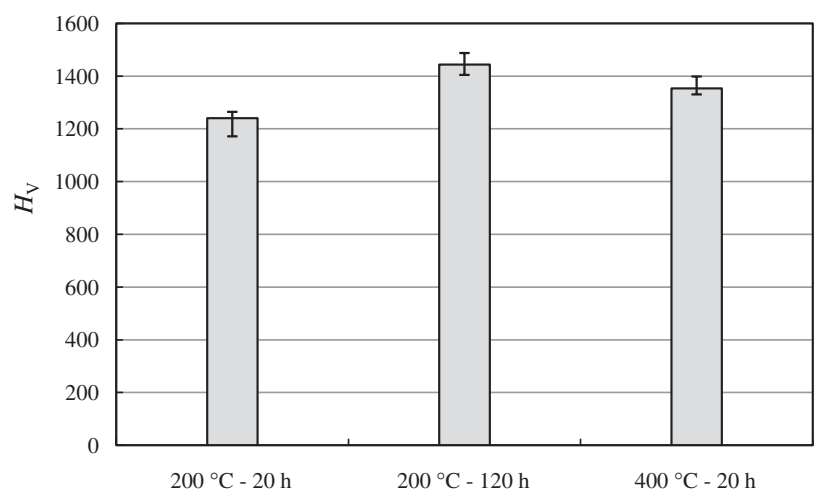

Fig. 4. Vickers hardness $H_{\mathrm{v}}$ of electrolyte ( $9.8 \mathrm{~N}$ load).

performed in the range of this study. However, when the YSZ powder was used without pre-sintering, the value of $R_{\mathrm{Z}}$ increased significantly.

As shown in Fig. 4, the Vickers hardness $H_{\mathrm{v}}$ of the electrolyte formed by pre-sintering at $200^{\circ} \mathrm{C}$ for $20 \mathrm{~h}$ is 1241 . By extending the pre-sintering time to $120 \mathrm{~h}$ at the same temperature of $200^{\circ} \mathrm{C}$, $H_{\mathrm{v}}$ increases to 1444 , which is about 1.2 times that of the above value. In the case of $20 \mathrm{~h}, H_{\mathrm{v}}$ increases from 1241 to 1354 when the pre-sintering temperature is increased from 200 to $400^{\circ} \mathrm{C}$. The depth of the indentation made with the indenter was estimated to be less than $6 \mu \mathrm{m}$ judging from the length of the diagonal line of the indentation. The depth was less than the electrolyte thickness of approximately $30 \mu \mathrm{m}$. Thus, although the specimen was a laminate composed of the electrolyte and the fuel electrode, the hardness of only the electrolyte could be measured.

An example of the $I-V$ (current density-terminal voltage) characteristics is shown in Fig. 5. This performance was measured with the cell fabricated using the YSZ powder presintered at $200^{\circ} \mathrm{C}$ for $120 \mathrm{~h}$. The $I-V$ characteristics of the cells fabricated by pre-sintering at $400^{\circ} \mathrm{C}$ for $100 \mathrm{~h}$ and $600^{\circ} \mathrm{C}$ for $20 \mathrm{~h}$ were similar to those shown in Fig. 5. However, the performances of the cells fabricated by pre-sintering at $200^{\circ} \mathrm{C}$ for $20 \mathrm{~h}$, at $400^{\circ} \mathrm{C}$ for $20 \mathrm{~h}$, and without pre-sintering were considerably lower than those under the aforementioned three conditions.

Figure 6 shows the relationship between the theoretical OCV (open circuit voltage) and the measured OCV. The measured OCVs under both the conditions without pre-sintering and at $200^{\circ} \mathrm{C}$ for $20 \mathrm{~h}$ are much lower than the theoretical values. However, when the pre-sintering time is extended to $120 \mathrm{~h}$, the measured OCVs at $200^{\circ} \mathrm{C}$ are close to the theoretical values. The good agreement between the measured OCVs and the theoretical

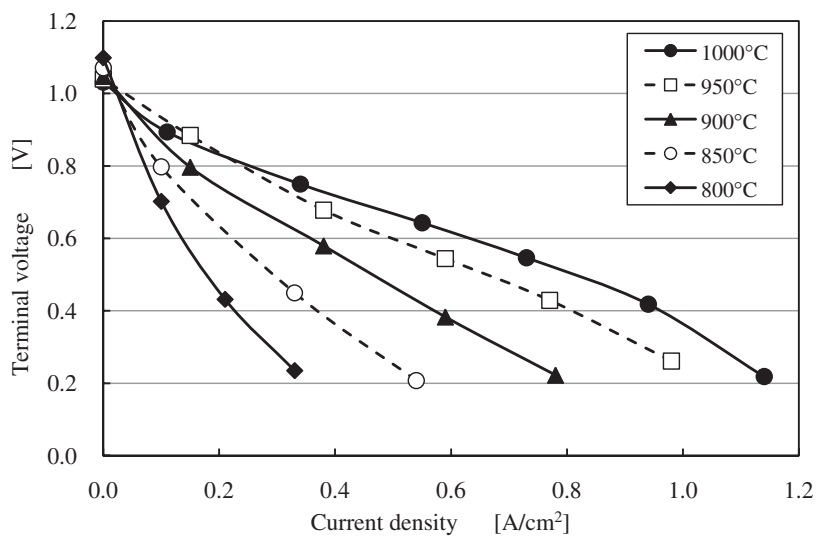

Fig. 5. $I-V$ characteristics of cell (pre-sintered at $200^{\circ} \mathrm{C}$ for $120 \mathrm{~h}$ ).

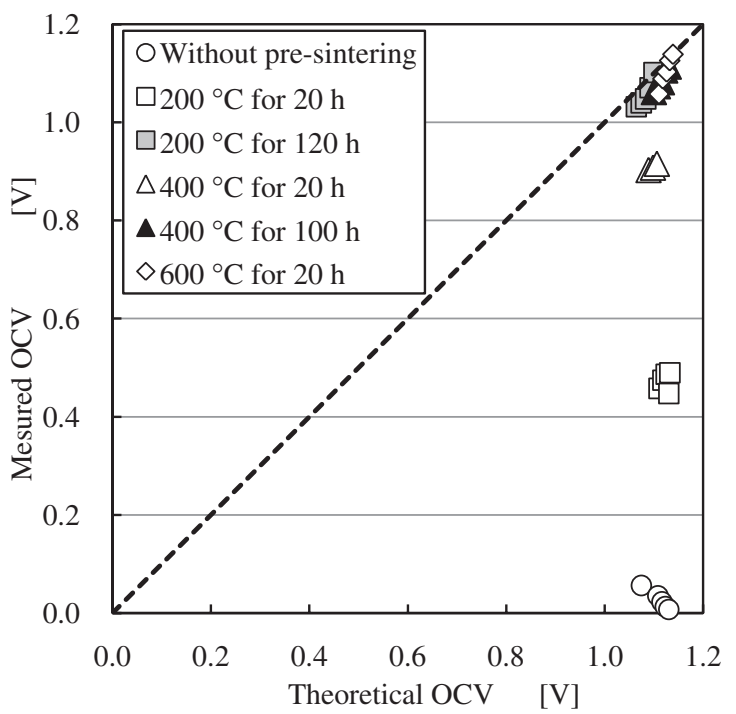

Fig. 6. Comparison of measured OCV with theoretical OCV (operating temperature: $800-1000^{\circ} \mathrm{C}$ ).

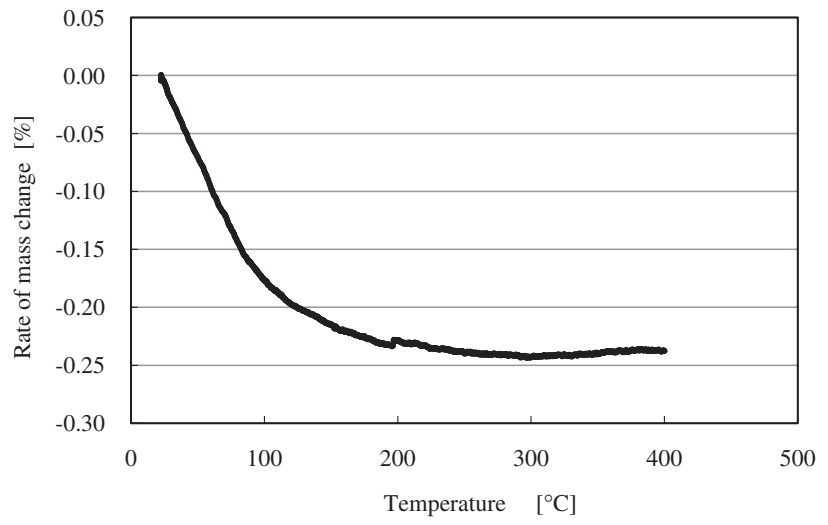

Fig. 7. TG curve of YSZ raw material powder (rate of temperature rise: $10.0^{\circ} \mathrm{C} / \mathrm{min}$, initial mass of sample: $22.062 \mathrm{~g}$ ).

OCVs indicates that the electrolytes are dense and have no crossleakage of gases. The results correspond to the SEM images as shown in Fig. 2. In the case of a pre-sintering time of $20 \mathrm{~h}$, the measured $\mathrm{OCV}$ is close to the theoretical value by increasing temperature to $600^{\circ} \mathrm{C}$. 
Pre-sintering causes the decrease of mass of the raw powder of YSZ as shown in Fig. 7 (thermo-gravimetric curve). The mass of YSZ powder decreases with increasing temperature up to about $200^{\circ} \mathrm{C}$, and then reaches a minimum. Judging from this result and the evaluation of the electrolytes, it seems likely that the raw powder has some absorbed water and its water has an effect on the sintering of the YSZ powder. However, there was no remarkable difference between the SEM image of the pre-sintered YSZ powder and that of the YSZ powder that was not pre-sintered. When comparing the SEM images of the depositional surfaces after dip-coating and before co-sintering, also, the surface appearance of the deposit made of the presintered YSZ powder was not significantly different from that made of the YSZ powder that was not pre-sintered. More detailed investigations are necessary to reveal the relationship between the sintering of the YSZ powder and the absorbed water.

\section{Conclusions}

When the YSZ electrolyte was deposited by a dip-coating method, the properties of the electrolyte depended on the process of pre-sintering of the YSZ raw material powder used in the suspension for the dip-coating method. The electrolyte fabricated using YSZ powder after pre-sintering at $200^{\circ} \mathrm{C}$ for $120 \mathrm{~h}$ was dense and impermeable. The cell containing the electrolyte showed reasonable power generation performance. When the time for pre-sintering was shortened to $20 \mathrm{~h}$ and the pre-sintering temperature was $200^{\circ} \mathrm{C}$, the electrolyte was found to be porous and the open circuit voltage of the cell was lower than the theoretical value. By increasing the pre-sintering temperature to $600^{\circ} \mathrm{C}$ for a pre-sintering time of $20 \mathrm{~h}$, an ideal electrolyte could be obtained. In contrast, the electrolyte fabricated using the YSZ powder without pre-sintering was very porous, and caused a considerable drop in open circuit voltage.

Acknowledgement The authors would like to thank the Instrumentation Center of the University of Kitakyushu for the use of the scanning electron microscope and laser scanning confocal microscope and for the cooperation of the center.

\section{References}

1) J. Larminie and A. Dicks, "Fuel Cell Systems Explained Second Edition," John Wiley \& Sons Ltd., UK (2003).

2) P.-W. Li, L. Schaefer and M. K. Chyu, "Transport Phenomena in Fuel Cells," ed. by B. Sundén and M. Faghri, WIT Press, UK (2005) pp. 1-41.

3) K. Murata and M. Shimotsu, Denki Kagaku, 65, 38-43 (1997).

4) A.-Q. Pham, B. W. Chung, J. J. Haslam, D. J. Lenz, E. F. See and R. S. Glass, Electrochemical Society Proceedings Vol. 2001-16, 148-154 (2001).

5) T. L. Nguyen, T. Honda, T. Kato, Y. Iimura, K. Kato, A. Negishi, K. Nozaki, M. Shiono, A. Kobayashi, K. Hosoda, Z. Cai and M. Dokiya, J. Electrochem. Soc., 151, A1230-A1235 (2004).

6) S. Mukerjee, K. Haltiner, R. Kerr, L. Chick, V. Sprenkle, K. Meinhardt, C. Lu, J. Y. Kim and K. S. Weil, ECS Trans., 7, 5965 (2007).

7) K. Eguchi, T. Setoguchi, T. Inoue and H. Arai, Solid State Ionics, 52, 165-172 (1992).

8) O. Yamamoto, Y. Arati, Y. Takeda, N. Imanishi, Y. Mizutani, M. Kawai and Y. Nakamura, Solid State Ionics, 79, 137-142 (1995).

9) B. C. H. Steele, Solid State Ionics, 129, 95-110 (2000).

10) T. Ishihara, H. Eto, H. Zhong and H. Matsumoto, Electrochemistry, 77, 115-122 (2009).

11) R. J. Kee, H. Zhu and D. G. Goodwin, J. Combust. Soc. Jpn., 47, 192-204 (2005). 